\title{
Capacity Development In The Implementation Of Community Protection In Surakarta City, Indonesia
}

\author{
${ }^{1,2}$ Joko Pramono, ${ }^{2}$ Y. Warella, ${ }^{2}$ Retno SunuAstuti, ${ }^{2}$ Hardi Warsono \\ ${ }^{1}$ Faculty of Social and Political Sciences, Slamet Riyadi University, Surakarta, Indonesia \\ ${ }^{2}$ Faculty of Social and Political Sciences, Diponegoro University, Semarang, Indonesia
}

Coressponding Author: Achmad Choerudin

E-mail : achmadchoerudin77@yahoo.co.id

\begin{abstract}
"Civil protection" is widely used around the world as a term that describes activities to protect civilian populations from incidents and disasters. Surakarta City, Central Java, Indonesia, also has a civil protection scheme. This scheme is regulated in the Surakarta City Regional Regulation No.12 of 2018 about the Implementation of Community Protection, through the Community Protection Unit (Satlinmas-SatuanPerlindunganMasyarakat). Satlinmas members are empowered to be able to support government efforts in creating security, peace and public order. This study aims to analyze how capacity development in the implementation of community protection in Surakarta City, Indonesia. The research method is descriptive qualitative by collecting data through observation, interviews and documentation. Data were analyzed using capacity building theory at the individual, organizational and system levels. The results found that the capacity building in Surakarta was still not optimal. At the individual level, Satlinmas members have not received adequate education and training. At the organizational level, there are no SOP (Standard Opera and other support regulations. At the system level, the policies made have not been able to fulfill the needs of Satlinmas members in carrying out their duties, main and functions optimally.
\end{abstract}

Keywords:

Capacity Development, Community Protection, Surakarta Indonesia.

Article Received: 18 October 2020, Revised: 3 November 2020, Accepted: 24 December 2020

\section{INTRODUCTION}

The phrase "civil protection" has been widely used around the world as a term that describes activities to protect civilian populations from incidents and disasters(Mauro, 1996). This civil protection is also used in Surakarta City, Central Java Province, Indonesia. In the Surakarta City Regulation Number 12 of 2018 concerning the Implementation of Community Protection, Satlinmas has the task of assisting in (1) disaster management; (2) public security, order and order; (3) in social activities; (4) handling of order, order and security in the administration of elections; and (5) State defense efforts. In this context, Satlinmas has a strategic role and function in helping the TNI (Indonesian National Army), Polri (Indonesian National Police), BPBD (Regional Disaster Management Agency) and Satpol PP (PamongPraja Police Unit) to fill the task that cannot be reached by these institutions to the lowest level.
Satlinmas members can be empowered and utilized to help the task that cannot be reached by the TNI, Polri, BPBD and Satpol PP quickly, precisely and directly serving the community. Anderson revealed that civil defense is managed by a combination of military and paramilitary forces acting under military regulations(Anderson, 1970). Another opinion, Masri and Moore revealed that civilian protection has gradually shifted from methods of command and control, to methods or forms of community and military collaboration and to share information(Masri \& Moore, 1995).

Based on the results of monitoring, evaluation and reporting of the Surakarta City's community protection unit in 2012, the Surakarta City Development Planning Agency stated that the Satlinmas condition in Surakarta was still perfunctory (Bappeda Kota Surakarta, 2012). There was no special advantage, so its existence 
should be questioned. Satlinmaswere only known as security guards at the village districts offices, or simply become a "busy section" when a member of the community has a feast or funerals. According to the Regulation of the Minister of Home Affairs of the Republic of Indonesia (Permendagri) Number 6 of 2012 concerning Early Community Awareness in Regions, Satlinmas is a form of community organizing prepared, compiled and equipped with knowledge and skills in the field of community protection facilitated by the government or regional government.

The function of protecting community also lacks enthusiasm in the eyes of the community. The same thing was conveyed by member of Commission I DPRD Surakarta, Budi Prasetyo, who stated that the performance of Satlinmas was not optimal. Satlinmas should have played more roles, such as to enforce local regulations (Putradi Pamungkas, 2016).This condition indicates a problem with the competency of the community protection unit's resources.

The sub-optimal role of the Satlinmas has an impact on the condition of security and public order. Based on the study of early detection of social vulnerability and crime in the city of Surakarta conducted by the Surakarta City Planning Agency in 2016, there was an increase in the number of social insecurity and crime(Bappeda Kota Surakarta, 2016).

Table 1: Criminality Level in Surakarta City 2014-2019

\begin{tabular}{|c|c|}
\hline Year & Number of Crime Cases \\
\hline 2014 & 280 Cases \\
\hline 2015 & 302 Cases \\
\hline 2016 & 1,182Cases \\
\hline 2017 & 1,065Cases \\
\hline 2018 & 905 Cases \\
\hline
\end{tabular}

Source: Study on Early Detection of Social Vulnerability and Crime in Surakarta City (2019) However, this condition would only be achieved when Satlinmas understand optimally about its main function and capacity according to the demands of the task. However, based on preliminary data obtained from the study of the effectiveness of the Satlinmas in Surakarta, there are still many Satlinmas members who did not understand their main tasks and functions(Bappeda Kota Surakarta, 2017). This data could be seen in the following diagram.

Picture 1: Satlinmas members' understanding of their main tasks

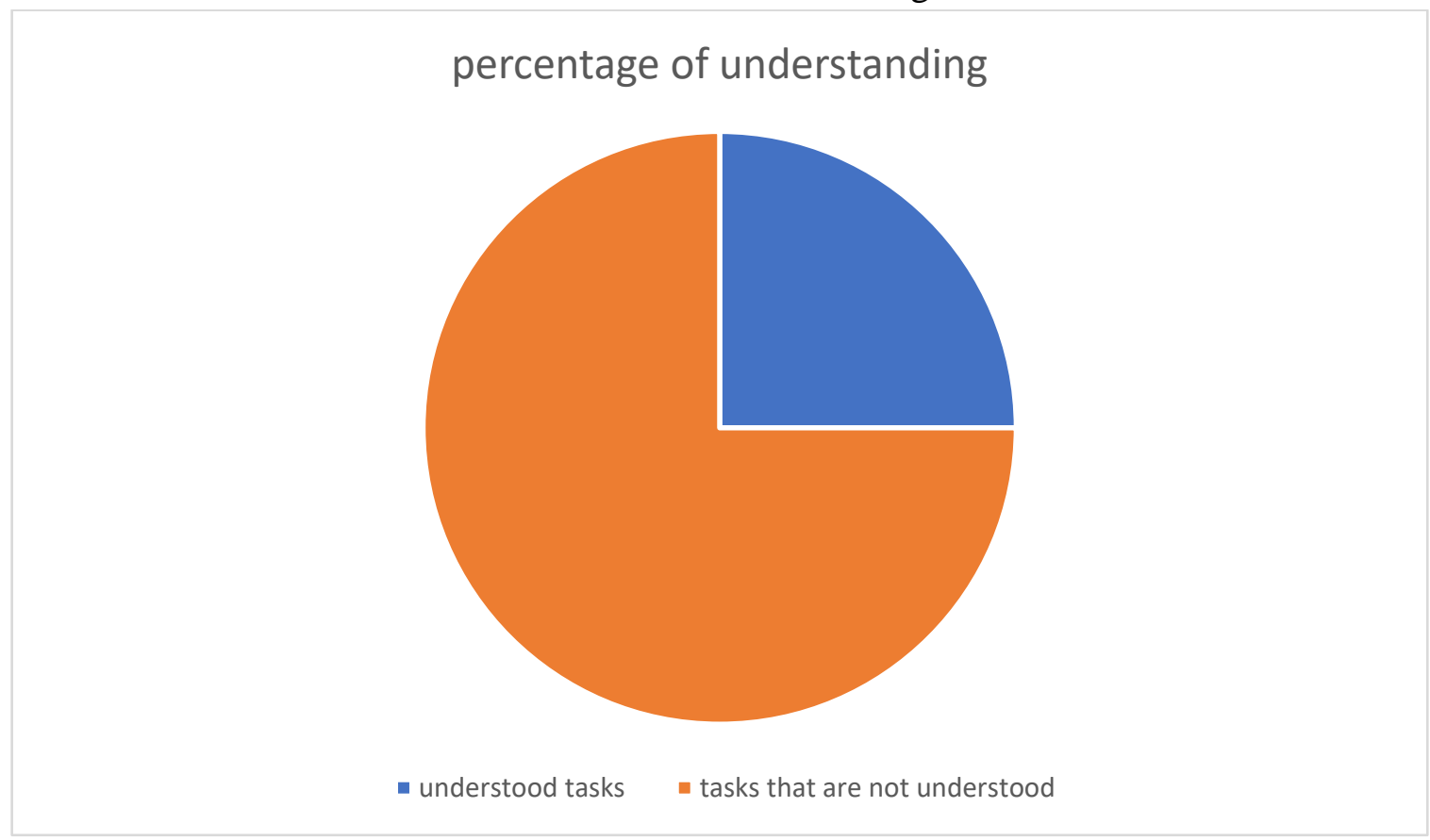

Source: Study on the Effectiveness of Satlinmas Surakarta City, 2017 
Based on this description, the capacity ofSatlinmas needs development. Human resource development is an important factor in capacity building. Gayani Karunasena and Dilanthi Amaratunga stated that capacity building must be carried out at the human resource and organizational level. Human resource development (individual and team) addresses issues related to skills and access to information, knowledge and training, providing effective performance of national entities(Karunasena \& Amaratunga, 2016).

Capacity building is one of the strategies that can be carried out in achieving organizational goals as stated by Daniel Rickett that the ultimate goal of capacity development was to enable the organization to grow stronger in achieving its goals and mission.(Rickett, 2016). Keban also said that capacity development is a series of strategies aimed at increasing the efficiency, effectiveness, and responsiveness of performance(Keban, 2000). From the various dynamics of problems and potentials currently owned by Satlinmas, researchers conducted research on capacity building in the implementation of community protection in Surakarta. The implementation of community protection is a form of basic service that must be fulfilled by the Surakarta City government. Researchers consider it important to be able to answer research questions of capacity building efforts in implementing community protection in the city of Surakarta. The city of Surakarta was chosen as the research location because the city of Surakarta is one of the regions in Indonesia that has compiled regulations in the form of regional regulations relating to the implementation of public protection.

\section{MATERIAL AND METHODS}

This research approach was descriptive qualitative research. Qualitative descriptive research was research that aims to describe, summarize various conditions, various situations or social reality phenomena that exist in the society that was the object of research and attempt to draw that reality to the surface as a feature, character, nature, model, or description of the condition, situation or certain phenomenon(Bungin, 2011).

This research was conducted in the Surakarta City Government, through the regional apparatus organizations involved and stakeholders in the implementation of community protection. This location was chosen because of the following considerations:

1. The very fast growth of Surakarta City will be followed by the social development of its people, including the problems of peace, security and increasing crime.

2. There are problems in implementing community protection, in organizing and empowering them.

3. The Surakarta City Government has rejected the dissolution of Satlinmas as regulated in the Presidential Regulation of the Republic of Indonesia Number 88 of 2014 concerning the Revocation of Presidential Decree Number 55 of 1972 concerning the Improvement of Civil Defense Organizations and People's Resistance and Security Organizations in Order to Control the Implementation of universal people's defense system (Peraturan Presiden Republik Indonesia Nomor 88 Tahun 2014 tentang Pencabutan Keputusan Presiden Nomor 55 Tahun 1972 tentang Penjempurnaan Organisasi Pertahanan Sipil Dan Organisasi Perlawanan Dan Keamanan Rakjat Dalam Rangka Penertiban Pelaksanaan Sistim , 2014), signed by the President of the Republic of Indonesia Susilo Bambang Yudhoyono on September 1, 2014.

4. There were three methods of collecting data in this research, namely: observation, interview and documentation study. Furthermore, the data obtained were used as material for data analysis. Data analysis was useful in answering the first and second problem formulations in research using interactive data analysis models (Miles \& Saldana, 2014), as shown in the image below: 
Picture 2: Qualitative Data Analysis Techniques

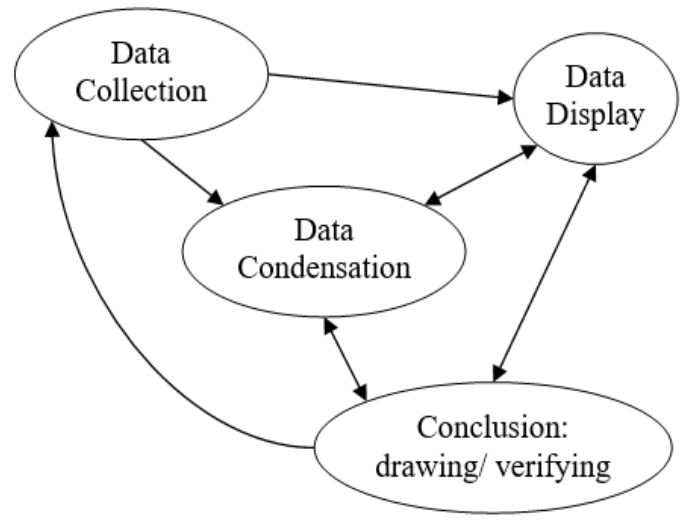

Source: Qualitative Data Analysis: A Methods Sourcebook

\section{RESULTS AND DISCUSSION}

Goodman and the team stated that capacity is the ability to carry out stated goals (Goodman et al., 1998). Manfred Poppe and Rainer Rohdewohld define that capacity development is a process that can increase the ability of a person, organization or system to achieve goals to be achieved. (Poppe $\&$ Rohdewohld, 2005). The same thing was also stated by KattySensions which defines that capacity building is usually understood as an effort to help government, society or individuals in developing the skills and expertise needed to achieve goals. Capacity building programs are designed to strengthen the ability to evaluate policy options and implement decisions effectively. Capacity building includes education and training, regulatory and institutional reform, knowledge, technology and financial assistance (Sessions, 1993).

This capacity building includes three levels of intervention as emphasized by Grindle (1997) and UNDP (1999), namely: individual / apparatus level, institutional level, and system level. Human resource development is an activity that must be carried out by organizations, so that their knowledge, abilities and skills are in accordance with the demands of the work being carried out. With this development activity, it is hoped can improve deficiencies in carrying out work better, in accordance with the development of science and technology used by the organization (Kadarisman, 2012).

Organizational Development is a program to increase organizational effectiveness by integrating common desires according to organizational goals (Robbins, 2010). An effective organization will make planned changes to all devices and systems, structure, culture, group dynamics, quality of human resources, strategies, and so on. The organizational development aspect focuses on the management system to improve the performance of existing functions and tasks and the microstructure regulation(Grindle, 1997).At the system level, the organization must improve the systems, policies and regulations as the basis of various programsand activities of the organization. In developing a quality system, the main focus is on changes policies and regulations that are considered to hinder the optimal performance of the organization.

Several popular concepts of capacity building can be explored from the various works of Milen (2006), Grindle (1997), and Leavit (2004) which state that the bond between determinant factors in capacity building is an integral whole. In the end, this capacity building should be used as a strategy to increase efficiency and effectiveness in achieving organizational goals (Djatmiko, 2004; Grindle, 1997; Milen, 2006).Capacity Building for Satlinmas can be a strategic parameter to support 
the realization of good governance. Satlinmas play a supporting role in supporting local governments in realizing peace, security and comfort of the community. Optimizing the Satlinmas capacity can support local governments in realizing the various programs implemented. This capacity development can be detailed in three levels of development, namely individual, organization and system level.

\section{Individual Level}

Individual level includes human resources. Capacity building at this level is the most basic because it focuses on the individual. HR development means a framework to assist individuals in developing personal skills, knowledge and abilities according to organizational needs. Human resources are an important asset that an organization must have in order to realize its existence to achieve an organizational goal. To achieve these goals, several aspects need to be formulated in order to map the portion of human resource development needed. The aspect of capacity building at the individual level on human resources in Satlinmas, includes several aspects such as: knowledge and competence; training; Recruitment, Termination and Use; Payroll; and Workplace Conditions.

Knowledge and competence are fundamental characteristics that a person needs to have in doing work. In this case, each individual Satlinmas member needs to have sufficient knowledge and competence according to the needs and environmental conditions. Given the broad task of Satlinmas assisting roles, it means that the knowledge and competencies needed by Satlinmas must extensive knowledge.

The broad role and responsibility of the Satlinmas was acknowledged by the Head of the Community Protection Development Division of the Surakarta Civil Service Police Unit, SectionoHeriyanto, $\mathrm{SH}$, as he conveyed in the interview. The informant stated that the Satlinmas in Surakarta City had a broad task. Satlinmas take a supporting role in social activities. In addition, when the Satlinmaswas able to solve a problem in the community, the problem will not be delegated to responsible stakeholders. He also conveyed that if the Satlinmaswere effectively empowered, then the possibility of the Satpol's duties was small. This shows that Satlinmaswill have a big role when they have optimal competence.

Satlinmas members must be physically strong because they are directly involved in the community. They also have to have extensive knowledge. Satlinmas members need to understand local regulations, and study legislation. Then, they would be able to play a supporting role in enforcing regulations and creating peace in society. However, the research found that the majority of Satlinmas did not understand the prevailing regulations or laws. In their work, Satlinmas also does not have an SOP (Standard Operating Procedure) as a reference. The absence of SOPs confuses the Satlinmas performance pattern. The majority of tasks were perceived as simply picketing and going around monitoring the situation. Many Satlinmas did not understand the extent of their authority when facing a threat, potential disaster or crime.

An SOP is a written document which contains detailed work procedures, with a step-by-step and systematic description. By reading the SOP, we can understand a series of instructions related to routine activities. Without SOPs, some aspects of work procedures may be difficult to understand. Moreover, the majority of Satlinmas have low levels of education. Low educational background, with low motivation and independent learning ability, further hinder the development of Satlinmas capacity.Satlinmas needs support from stakeholders in fostering and strengthening knowledge and competence.

However, stakeholder support for strengthening knowledge and competence was still considered low. So far, knowledge development has been mostly done individually. This depends on the 
willingness of each individual to learn independently. In fact, referring to Article 19 Permendagri No 84/2014, it is stated that Satlinmas members have the right to education and training. In Surakarta City, the responsibility for this training is handed over to the Satpol PP as the Linmas supervisor.

The training programs implemented and coordinated by the Satpol PP have so far not touched Satlinmas members as a whole, or only a partial. Information obtained from Satpol PP states that the education and training provided was targeted to reach all Satlinmas members. However, due to budget constraints, the training was carried out in turns. Satlinmas members who have not been able to attend the training, need to queue until it was their turn to take part in the training. And this queue took many years. Several Satlinmas who had the interest and motivation to develop themselves admitted that they were blocked by this training quota limit. In fact, the need for an understanding of this knowledge and competence was needed by all Satlinmas members without exception, since their first time in duty.

Training as capacity development ofSatlinmaswas given unevenly. This training is important because of the demand that Satlinmas must be able to help maintain securityand order in society. This was in accordance with the Satlinmas assignment regulated in Permendagri No. 10 of 2009 concerning the assignment of community organizations in terms of handling security, peace and order, and also particularly in the administration of elections. Satlinmas members were prepared and equipped with knowledge and skills in carrying out activities, such as natural disaster protection, to reduce the impact and minimize the consequences of disasters, and to assist and play a role in social activities in the community. Without sufficient provisions, it was difficult to have early alertness or carry out early detection of potential disasters.
Satlinmas members have started their duties since they received a Certificate of Appointment. Meanwhile, these conditions were increasingly overlapping, because if we return to the definition of Satlinmas in the Permendagri, it is stated that, "Community Protection Unit, hereinafter referred to as Satlinmas, is an organization formed by the Sub-district government and consists of members of the community who are prepared and equipped with knowledge and skills to carry out disaster management activities in order to reduce and minimize the consequences of disasters, as well as participate in maintaining security, peace and public order. community social activities. "

Should a person be called Satlinmas, only when he or she has been prepared and equipped with the required knowledge and skills. However, this was not be done in Surakarta City. The absence of preparation and debriefing given to each member of the Satlinmas on duty was also an obstacle to the Satlinmas performance. Moreover, the initial selection of Satlinmas was not done based on competence. In fact, the World Bank on (Haryanto, 2014)states that one of the aspects of capacity development lies in the process of recruitment, termination and utilization of employees which are carried out in a professional, managerial and technical manner.

Recruitment is an important aspect because it relates to the readiness of HR. The right recruitment will produce the right human resources. Ideally, recruitment was done rigidly and complies with existing regulations, while at the same time adjusting to needs. The mandate of Article 4 paragraph 2, Permendagri No 84/2014, states that the recruitment of community service units should be carried out based on the following requirements: (a) Indonesian citizens; (b) be devoted to God Almighty; (c) loyal to Pancasila and the 1945 Constitution of the Republic of Indonesia; (d) at least 18 (eighteen) years of age and / or already married; (e) Minimum education level of Junior High School; (f) physically and mentally healthy; $(\mathrm{g})$ residing in the local Village 
(Kelurahan) area; and (h) willing to make a statement to become a member of Satlinmas voluntarily and the ability to be active in community protection activities.

Overall, there is no requirement that Satlinmas have the required competencies. This is the initial problem in the effort to fulfill Satlinmas competences. Furthermore, the conditions points (a) to $(\mathrm{g})$ are general requirements that are easy to fulfill. The condition for point (h), namely the willingness to carry out work in a voluntary scheme, is a condition that is often ignored. The voluntary principle is intended that Satlinmas members are not financially oriented. Being a community service unit is a form of dedication of a citizen to society. This point also bringsSatlinmas in carrying out its various main tasks and functions, cannot be called as a "work". This resulted in the absence of a payroll system or incentives in the Satlinmas. It is hoped that people who become Satlinmasalready have other main "jobs" or financial sources.

Contrary to this principle, the research found that the majority of Satlinmas members became "Satlinmas" and thought to be their main job to get salary.The consequence wasthey expect of getting "salary" or "incentive" or other financial gain from the service activities. According to the regulation, Satlinmas does not have a payroll scheme or salary. They only got operational costs. This scheme also lowers public interest in becoming Satlinmas members. This resulted in the human resources who entered as members of Satlinmas having low competency provisions.

The principle of volunteering contradicts the payroll system as it is commonly used as a basis for employee performance in companies. This is because volunteering itself refers to an individual or group activity to provide services without expecting financial gain. If Satlinmas members are based on the principle of volunteering, naturally there is no expectation of salaries, incentives or allowances for their various activities. The financial component in financial management is only in the form of operational costs as per Permendagri No 84/2014 Article 19 which states that the right of Satlinmas members is to obtain operational costs to support the implementation of tasks. This was different from salary.

In Surakarta City, Operational Costs were managed by the village and taken from the village funds. The value of this operational cost was equivalent to the Regional Minimum Wage when Satlinmas work 29 days in a month, 8 hours of work per day. The working hours are more than the standard working hours of laborers or employees. In fact, a Satlinmaswas unable to work 29 full days in a month because of the picket system. This means that Satlinmas members receive operational costs that were less than the regional minimum wage. In fact,these operational costs were considered a salary because they do not hold voluntary principles. This condition creates a perception that the Satlinmas welfare was below standard.

In fact, operating costs were not the same as salaries. In the payroll system in general, salary plays a role in increasing motivation so that they were able to carry out their job more effectively, improve performance, and increase productivity. This was also an important consideration when developing capacity for human resources, by increasing salaries and incentives. However, for Satlinmas, the payroll component cannot be used. This condition often makes Satlinmas feel that their performance was under-appreciated. In the end, this has an impact on performance and motivation to develop their capacity.

Moreover, the Satlinmas obligation to wear complete uniforms when on duty was not fully facilitated by the government. While on duty, Satlinmaswere required to wear uniforms with complete attributes including operational equipment, from hats to special shoes. However, only uniforms were provided, and that was limited. There were those who only wear used 
uniforms from the old Satlinmas who have stopped working. This condition was exacerbated by the low perception of the community towards Satlinmas. Satlinmas members admit that at work, they were often looked down upon by the community. This negative image was related to the Satlinmas competency which was considered less qualified.

\section{Organizational / Institutional Development}

Organization is an important determinant of capacity building. Organization is defined as a consciously coordinated social unit, with relatively identifiable boundaries, working on a continuous basis in order to achieve a common goal or group of goals. The organization has a structure that defines how tasks will be divided, who reports to whom, as well as the formal coordination mechanisms and interaction patterns that members need to follow. Organizational design emphasizes the management side by considering constructs in order to achieve organizational goals (Robbins, 1994: 4-7).

Organizational development needs to be done in order to achieve capacity building for Satlinmas. This organizational development analysis was described in several aspects including: management and organizational structure; organizational culture; decision making system; resource; communication and coordination; and an incentive system. Organizational structure is understood as a formal organizational framework that becomes a reference so that work tasks are divided, grouped and coordinated (Robbins, 2008). The organizational structure must be in line with the organizational strategy. The organizational structure becomes a reference in the process of reviewing and configuring the structure, process, reward system, and activities of people or individuals in the group so as to create an effective organization.

In capacity development forSatlinmas, division of labor, hierarchy and coordination were needed in order to build an ideal organizational structure. Meanwhile, the departmentalization element refers to the relationship at the top level because Satlinmaswas already a separate entity. Satlinmaswas a small part of local government that was built with the aim of helping achieve community welfare. In this case, local governments were obliged to improve community empowerment and welfare. The government must be able to create public order by maintaining peace in society. In order to achieved the goals, the government had been formed a regional government apparatus tasked with creating public order and maintaining peace in society, in the form of a Civil Service Police Unit (SatPolPP). Satpol PP was built with the main objective of assisting the Regional Head in organizing the General Government, with the main tasks of fosteringorder, as well as enforcing the Legislation and Regional Regulations.

In carrying out its task of maintain peace in the community, the Surakarta Satpol PP was assisted by the Community Protection Unit (Satlinmas). This coordination line places the Satlinmas under the coordination of the Satpol PP. Satpol PP works at the City level, while Satlinmas work in the region or in sub-districts. Based on the Surakarta City Regional Regulation No.12 of 2018 concerning the Implementation of Community Protection, it explains that the Satlinmaswas located in the village. This means that the Satlinmas coordination structure was under the Municipal Government of Surakarta, Satpol PP, sub district, as an extension of the regional government.

The research found that the division of labor in the Satlinmas Kota Surakarta was mostly left in the sub district. This also applies to hierarchy and coordination whose dominance was controlled at the sub district level. At a higher level, coordination between the Satlinmas in various sub district takes place at the City level, by the Satpol PP, which was more specifically carried out by the Satlinmas Institution. 
The development of institutional capacity refers to culture strengthened. Organizational culture systems can drive the direction of achieving effective goals by developing leadership strategies, communication and value systems. From the results of data analysis obtained, Satlinmas Surakarta built an organizational culture that was able to have a positive effect in the implementation of various work activities. Referring to PP. 59 of 2012 concerning the National Framework for Regional Capacity Development in terms of organizational culture, it is known that institutional capacity development places indicators in the institutionalization of a productive and positive organizational work culture on the basis of the noble values of the nation's culture. Research conducted on Satlinmas Surakarta City shows that there was a value system that forms the basis of ethics at work.

The work culture value system that was applied such as politeness, warm hospitality, and communication that shows the noble values of the Indonesian people. Satlinmas carry out their duties by upholding participatory and democratic values when engaging in the community. This was also related to the high culture of values, norms and ethics that prevail in the people of Surakarta City in general, such as manners and the culture of mutual cooperation. From here, there was work motivation that allows us to always develop.

On the other hand, the discipline value for some Satlinmas members was low. Based on voluntary principles, it was difficult to apply the value of employee discipline as in government regulations No. 53 of 2010 concerning Employee Discipline. In this government regulations, tighter supervision can be carried out and the punishment is stricter and harsher. In connection with the status of Satlinmas who are not considered as employees, this value of discipline cannot be enforced. The Satlinmas work ethic depends on the character development provided through various education and trainings. Meanwhile, education and training were not yet clearly structured.
The analysis of the research conducted shows that in general, Satlinmas have low formalization in their organization. Low formalization affects the behavior of Satlinmas members. In some sub districts, there appears to be an indecisive decision-making, which means that members have a lot of freedom in carrying out their work. The main problem in the Satlinmas in Surakarta regarding the decision-making system lies with the Satlinmas leaders in each work unit or in the sub district. Each sub district has its own character and policies, with minimal organizational centralization at the city level. At the City level, organizational centralization related to clarity of organizational policies, work control and coordination, decision making and employee participation has not run optimally. Although there were community line agencies at the city level that are tasked with coordinating the Satlinmas members at the village level, this coordination has not been optimal.

The total number of government agencies in Surakarta wasonly ten people. These ten people were in charge of coordinating Satlinmas in all urban villages in the city of Surakarta (54 kelurahan). There were times when coordination did not go well because these Satlinmas Institutions also carry out many tasks in Satpol PP. Moreover, the Satlinmas Administration itself only has a line of coordination with Satlinmas members, while there was no formal authority and coordination with the village head, as the direct supervisor of the Satlinmas members. This condition drives decision making overlaps between the Satpol PP, the Satlinmas Institution, and the Head of the Village.

In addition, the current system showed decentralization at the sub district level. In that sense, between one urban village and another, there was no meaningful uniformity and continuity. Decision-making takes place partially at the village level and rarely at the city level. This condition makes the decision-making system 
dependent on the authority of the village head. In fact, policies related to additional education and training for Satlinmas members other than the training provided by the Satpol PP, also depend on the village head's policy.

This condition results in unequal system of Satlinmas decision-making throughout Surakarta. This was also influenced by the low application of formal rules, such as mechanisms and procedures related to performance. Another impact was the low initiative of Satlinmas members in working. The research found that Satlinmas members were lack initiative,less responsive and there were various misunderstandings in translating tasks and functions, as well as the rules in carrying out their helping role. This gives rise to conditions of inability to carry out tasks optimally. This condition also affects the degree of achievement of Satlinmas performance as a whole in carrying out an assisting role in society.

The results showed that an indecisive decisionmaking system, as well as unclear hierarchy and coordination contributed to a lack of responsibility for Satlinmas members. Satlinmas members perceive that the authority given was only limited due to its function which was considered merely an "auxiliary role". This makes Satlinmas members feel reluctant to make decisions when they face problems that occur in society. The Satlinmas function which was considered merely an assisting role was also the perception of the Linmas coach. Referring to the informant's statement, the Head of the Community Protection Development Division of the Surakarta Civil Service Police Unit, SectionoHeriyanto, SH, who stated that, "His limits and powers are an auxiliary role. He has no suppression function"(interview, 11 April 2020).

Based on the Republic of Indonesia Law No. 3 of 2002 on National Defense which regulates against Military Threats, the universal defense system places the Indonesian National Army as the main component supported by the reserve and supporting components. Furthermore, referring to Law No. 23/2014 on Regional Government, Satpol PP and Satlinmas are parts of regional apparatus in the field of Regional Regulation Enforcementand public order, which have special skills, fighting spirit and high discipline and have a hierarchy, command. Satpol PP and Satlinmas are part of the HR supporting components that are believed to be in the national guard.

Communication and coordination were needed in capacity development. Communication and coordination means building networks that were oriented towards completing tasks and carrying out organizational functions. Networks can be arranged on both internal and external organizations. In this case, Satlinmas Surakarta did it directly and by utilizing technological media. The technology media used was the SIMPELMAS application for reporting, monitoring and evaluation. SIMPELMAS was used specifically for Satlinmas in the Surakarta City area. They also had SIMAS, thatwas used at the Central Java Province level. In addition, the WhatsApp (WA) group was also used. WA was considered the easiest and fastest medium to use. By utilizing WA media, communication and coordination can be more quickly, especially when they on duty. Responses from members and stakeholders can be obtained quickly, especially when facing urgent conditions or emergencies.

However, there were still obstacles in this communication and coordination network. There were still several Satlinmas members who did not have smartphones so they cannot access information such as SIMPELMAS, SIMAS, and WA. Some did not have any internet connection. Thus, some members also rely on the WIFI internet network in the village. This condition restricts their access to the group when they were outside the village office or while on patrol. The government does not provide this communication facilities. Each Satlinmas member must use their own smartphone media and their own internet 
access. Because of this condition, work structure not being implemented effectively.

Satlinmas organizational development was also limited due to the absence of an incentive system. Incentives were a form of providing financial support to workers beyond salary. Work incentives were considered as recognition of the work performance and contributions of its members to the organization. The provision of incentives has the main function of giving responsibility and encouragement to employees. Regarding performance, several studies have shown that incentives have a positive and significant effect on performance (Meutia, 2015); (Indrawati, Hutagaol and Affandi, 2015); (Handoko, Waluyo: 2017). However, the limitation of Satlinmas which departs from the voluntary principle means that Satlinmas do not have the opportunity to get incentives. Satlinmas who feel that their welfare was still minimal has hopes of getting incentives. However, the realization was not possible.

\section{System Development}

In capacity development, the system development dimension is considered the highest level. This is because the system includes all components of capacity development. The system framework deals with the basic regulations, policies and conditions that support the achievement of the objectivity of a policy. In developing the Satlinmas capacity at the system level, local governments have a big role to play. Local governments have the authority to build community life collectively in accordance with the mandate of the law in the form of regional autonomy. Therefore, the development of civil society as expected depends on the existence and role of local governments as well as their apparatus. In this case, the development of Satlinmaswas influenced by how much attention the local government has on this unit.

Local government is the party capable of building a system for strengthening the capacity of the apparatus, organizational structure and regulatory system. This is also local government accountability in the process of regional governance in accordance with the mandate of Law Number 32 of 2004 concerning Regional Government. System development is described in several aspects including: rules and regulations; supporting policies; budget and financial support; program; relations between institutions; the situation that affects.

Rules and regulations are included in reforming policies at a macro scale. These rules and regulations can underlie the steps of the Satlinmas members in carrying out their duties and functions optimally. In managing Satlinmas in Surakarta City, several main rules were used as references:

- The 1945 Constitution

- Government Regulation No. 6/2010 concerning Civil Service Police Units

- Law Number 23 of 2014 concerning Regional Government

- Regulation of the Minister of Home Affairs of the Republic of Indonesia Number 84 of 2014 concerning Implementation of Community Protection

- Regulation of the Minister of Home Affairs of the Republic of Indonesia Number 42 of 2017 concerning Implementation of Capacity Building for Community Protection Unit Members

- Regional Regulation Number 12 of 2018 concerning Implementation of Community Protection (LINMAS)

These various regulations have become the main reference in the implementation of Satlinmas and also for the development of the Satlinmas capacity in Surakarta City. In addition, was necessary to formulate regulations that were able to support capacity building efforts and be implemented consistently. One of the supporting policies commonly used in capacity building efforts was a reward and punishment system. Referring to Article 19, Permendagri No 84/2014, it is stated that Linmas Members are entitled to a certificate 
of appreciation for those who have served for 10 (ten) years from the Regent / Mayor, 20 (twenty) years from the Governor, and 30 (thirty) years from the Minister of Home Affairs. There is a reward in the form of a certificate of appreciation for service achievements based on the length of time served. However, until now no one had received it, considering that the implementation of the legislation has not yet reached 10 years.

As for punishment, based on Article 14 paragraph 2, Surakarta City Regional Regulation Number 12 of 2018 concerning Implementation of Community Protection, it is explained that every Satlinmas member who violates the provisions is subject to administrative sanctions in the form of a written warning and / or dismissal. So far, administrative sanctions have been imposed for Satlinmas members who did not carry out their obligations. However, for light sanctions, it was mostly done in the form of verbal warning, not written warning. Meanwhile, for members of Linmas who had committed serious disciplinary violations, some had received sanctions such as dismissal.

System development is also related to budget. In the Regional Regulation of the City of Surakarta Number 12 of 2018 concerning the Implementation of Community Protection, it is stated that the funding for Satlinmas needs comes from the Regional Revenue and Expenditure Budget, and is adjusted to the regional financial capacity. However, it does not rule out outside funding. In Article 19, it states the provisions related to community participation in Community Protection which, if they voluntarily care about the tranquility, orderliness and comfort of the environment, can participate in two things, namely conveying information related to disturbances of order, tranquility and comfort of the environment; and / or funding.

So far, Satlinmas funding has relied on the Surakarta City Regional Budget. This budget is used for the purpose of personnel procurement, procurement of equipment and infrastructure, procurement of uniforms and honoraria. However, the budget value which was only $0.7 \%$ of the total regional budget of Surakarta City was still considered not optimal to accommodate the needs of Satlinmas throughout Surakarta City. The facilities and infrastructure obtained by Satlinmaswere still minimal. The procurement of official uniforms was limited, and attributes were also not facilitated. The budget limitations in Surakarta City were influenced by the fact that there are still officials or stakeholders who perceive that the role of Satlinmaswas low.

This also resulted in minimal capacity building programs. Satlinmas development has been regulated in the Regulation of the Minister of Home Affairs of the Republic of Indonesia Number 42 of 2017 concerning Implementation of Capacity Building for Community Protection Unit Members. In Surakarta City, the empowerment of Satlinmas is also regulated in the Surakarta City Regional Regulation Number 12 of 2018 concerning the Implementation of Community Protection. Article 12 states that capacity building is carried out in several ways, namely: (a) education and training; (b) increased participation and initiatives; (c) increased preparedness; $d$. emergency response handling; (e) control and operation; and (f) provision. It was further explained that the empowerment of Satlinmas members was carried out by setting up a post in each village. The development of the Satlinmas capacity in the City of Surakarta was largely left to the respective Village. The village head was the most decisive party in building the capacity of Saltinmas. In practice, many capacity buildings programs had been carried out by various parties for the development of community service units in Surakarta. This program was carried out at various levels, starting from the Central Government, Local Government, and non-government organizations such as NGOs and universities. However, the distribution of this program needs to be improved. 
The relationship between institutions in this case was useful for building a task network dimension. The task network dimension refers to a group of organizations that were involved in the completion of a specific task or goal. The development of this network can be made from various parties who have the support or resources to support the achievement of the Satlinmas empowerment goal. Many stakeholders outside of the Satlinmas have helped build the capacity of the Satlinmas such as the firefighters, regional disaster management agency, Indonesian Red Cross, National Search and Relief Agency, National Armyand Police. Satlinmas synergizes with Babinsa (Part of National Army) and Bhabinkamtibmas (Part of Police) who also work in the village every day.

So far, various other organizations, both from the government sector and outside the government, have shown consistency in helping to support the Satlinmas capacity. This support was provided by becoming a resource person for training programs and the like. However, there was no official agreement such as the MoU, which binds these various organizations in a particular network. This means that there was no consequence when there was no action taken to support the empowerment of Community Service units. In fact, the role of Satlinmaswas basically to play a supporting role for many other parties in terms of disaster and public order. The synergy was not optimal because the education and training that was being held unable to reach all Satlinmas personnel. This can be seen from the limited outreach activities. This study reveals that the capacity building practices that have been implemented for the development of community service units' capacity in Surakarta are still not optimal.

Conditions in the field indicate that the Satlinmas position tends to be neglected in government programs in Surakarta City. Attention to Satlinmaswas minimal. So far, the use of Satlinmas has been limited to traveling and patrolling to see the surrounding conditions in the community. However, in terms of Satlinmas participation in community empowerment was still minimal, or almost non-existent. For example, the environmental awareness movement, such as the one in recent years, has been prominently conveyed by the Surakarta City Government with the tagline "MasdarBersayakMasyarakatSadarBerantasSarangNyamuk" or The Conscious Society to Eradicate Mosquito Lives. The movement that was initiated to minimize the Dengue Hemorrhagic Fever epidemic that affects many Surakarta residents was an interesting community empowerment program. In practice, the involvement of Satlinmas to conduct socialization and education for the community in this program was minimal. Various other programs, such as socialization on maintaining the cleanliness of rivers, parks and others, also did not involve the Satlinmas. This condition at the same time shows the situation that the organs in the Surakarta City Government work partially. In addition, it can be assumed that Stakeholeders' trust in the Satlinmas competence in supporting socialization and education to the public was still minimal.

\section{CONCLUSION}

Capacity building efforts in implementing community protection in Surakarta can be analyzed in three levels of capacity building, namely at the individual, organizational and system levels. The individual level was related to human resources, in this case the Satlinmas personnel. Human resource capacity development limitations occur due to the limited training and education received by Satlinmas personnel. In fact, the Satlinmas task was very broad and requires extensive knowledge and competence. In addition, the principle of volunteering as Satlinmas personnel was no longer relevant and did not match the reality. At the organizational level, it was known that the Satlinmas development responsibility lied with the Satpol PP. Coaching was carried out through routine education and training, as well as coordination through the Satlinmas institutions. However, budget limitation in education and training 
restricts Satlinmas personnel to get comprehensive training. Many Satlinmas personnel did not have the opportunity to attend training and education. Much coaching was actually left to the village. This made the Satlinmascapacity development partially ongoing and depends on the policies of each village. This condition correlates at the system level, which indicates that the management system for implementing public protection requires a lot of adjustments. Satlinmas has a role to assist in supporting the implementation of community protection. However, the synergy of various Regional Apparatus Organizations to increase the Satlinmas capacity was still minimal. Besides, as a volunteer, the Satlinmas responsibility was too large. This research found that capacity development for implementing community protection in the City of Surakarta to not run optimally.

\section{REFERENCES}

[1] Anderson, W. A. (1970). Military Organizations in Natural Disaster. American Behavioral Scientist, 13(2), 415-422.

https://doi.org/10.1177/000276427001300 311

[2] Bappeda Kota Surakarta. (2012). Hasil Monitoring Evaluasi dan Pelaporan Satuan Perlindungan Masyarakat Kota Surakarta Tahun 2012. Bappeda.

[3] Bappeda Kota Surakarta. (2016). Kajian Deteksi Dini Kerawanan Sosial dan Kriminalitas Kota Surakarta Tahun 2016. Bappeda.

[4] Bappeda Kota Surakarta. (2017). Efektivitas Satlinmas Kota Surakarta. Bappeda.

[5] Bungin, B. (2011). Penelitian Kualitatif. Kencana Predana Media Group.

[6] Djatmiko, Y. H. (2004). Perilaku Organisasi. Alfabeta.

[7] Goodman, R. M., Speers, M. A., McLeroy, K., Fawcett, S., Kegler, M., Parker, E., Smith, S. R., Sterling, T. D., \& Wallerstein, N. (1998). Identifying and
Defining the Dimensions of Community Capacity to Provide a Basis for Measurement. Health Education and Behavior, 25(3), 258-278. https://doi.org/10.1177/109019819802500 303

[8] Grindle, M. S. (1997). Getting Good Government: Capacity Building in the Public Sectors of Developing Countries. Harvard Kennedy School.

[9] Haryanto. (2014). Pengembangan Kapasitas Kelembagaan (Institutional Capacity Development) (Teori dan Aplikasi). AP21 Nasional.

[10] Kadarisman, M. (2012). Manajemen Pengembangan Sumber Daya Manusia. PT Raja Grafindo Persada.

[11] Karunasena, G., \& Amaratunga, D. (2016). Capacity Building for Post Disaster Construction and Demolition Waste Management: A Case of Sri Lanka. Disaster Prevention and Management, 25(2), 137-153. https://doi.org/10.1108/DPM-09-20140172

[12] Keban, Y. T. (2000). "Good Governance" dan "Capacity Building" sebagai Indikator Utama dan Fokus Penilaian Kinerja Pemerintahan. Naskah, Juni(20), 1-12.

[13] Masri, A., \& Moore, J. E. (1995). Integrated Planning Information Systems: Disaster Planning Analysis. Journal of Urban Planning and Development, 121(1), 19-39.

https://doi.org/10.1061/(ASCE)07339488(1995)121:1(19)

[14] Mauro, A. (1996). We All are Civil Protection! Stop Disasters, 29(1), 3-4.

[15] Milen, A. (2006). Capacity Building Meningkatkan Kinerja Sektor Publik. Pembaruan.

[16] Miles, M. B. ., \& Saldana, M. H. (2014). Qualitative data analysis: a methods sourcebook. Arizona State University.

[17] Peraturan Presiden Republik Indonesia Nomor 88 Tahun 2014 tentang Pencabutan 
Keputusan Presiden Nomor 55 Tahun 1972 tentang Penjempurnaan Organisasi Pertahanan Sipil Dan Organisasi Perlawanan Dan Keamanan Rakjat Dalam Rangka Penertiban Pelaksanaan Sistim, (2014).

[18] Poppe, M., \& Rohdewohld, R. (2005). Guidelines on Capacity Building in the Regions Module C: Supplementary Information and References.

[19] Putradi Pamungkas. (2016). Penghapusan Linmas Kota.

[20] Rickett, D. (2016). Capacity Building.

[21] Robbins, S. P. (2010). Teori Organisasi: Struktur, Desain dan Aplikasi (Alih Bahasa Jusuf Udaya (ed.)). Arcan.

[22] Sessions, K. (1993). Building the Capacity for Change: The World Stands Ill Prepared to Address Problems That Cut Across Sectors and Boundaries. EPA Journal, 19(2), 15-19. 